\title{
Thoracic splenosis: correct imaging diagnosis prevents invasive procedures like biopsy and thoracoscopy
}

\author{
Rajesh Thampy, Chakradhar R Thupili
}

Department of Diagnostic and Interventional Imaging, McGovern Medical SchoolUTHealth, Houston, Texas, USA

\section{Correspondence to} Dr Rajesh Thampy, rajesh.thampy@uth.tmc.edu

Accepted 12 October 2018
Check for updates

(c) BMJ Publishing Group Limited 2018. No commercial re-use. See rights and permissions. Published by BMJ.

To cite: Thampy $R$, Thupili CR. BMJ Case Rep Published Online First: [please include Day Month Year]. doi:10.1136/bcr-2018227355

\section{DESCRIPTION}

A 48-year-old woman presented to the emergency department with acute shooting type of left-sided chest pain. There was no radiation of the pain to the arm, no aggravating or relieving factors. The patient denied cough, haemoptysis or weight loss. Medical history was significant for stage 2 breast carcinoma treated with radical mastectomy and radiotherapy 5 years ago. Since then she was on hormone therapy with tamoxifen. Investigations including routine blood counts, ECG and cardiac enzymes were normal. Chest radiograph did not reveal any abnormalities. CT scan of the chest with intravenous contrast revealed three enhancing pleural based masses in the left hemithorax, measuring up to $2.6 \mathrm{~cm}$ in size. Initial diagnosis was pleural metastases from breast carcinoma and biopsy was considered. But the images also revealed bullet fragment in the thoracic spine and postsurgical changes of splenectomy. This raised the suspicion that the pleural masses could be due to splenic tissue which got auto implanted in the chest during splenic and diaphragmatic injury. On detailed history taking, the patient confirmed history of abdominal surgery for gunshot injury 20 years ago. To confirm that it is splenic tissue, a technetium $99 \mathrm{~m}$ sulfur colloid scan was done, which showed tracer uptake in the left hemithorax corresponding to the masses detected on CT scan, thus confirming that it was splenic tissue. The chest pain was relieved by nonsteroidal anti-inflammatory drugs and the patient was discharged. Although exact cause of the patient's chest pain is unclear, it is unlikely due to splenosis since there were no inflammatory changes surrounding the masses and splenosis had been present since the surgery 20 years ago. The pain could have been secondary to radiotherapy.

Splenosis is defined as heterotopic auto transplantation and implantation of splenic tissue after trauma. It can occur anywhere in the peritoneal cavity. But to produce intrathoracic splenosis simultaneous diaphragmatic and splenic injury or surgery
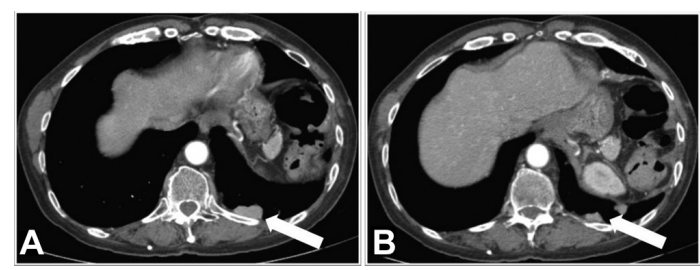

Figure 1 Contrast-enhanced axial CT images of the thorax shows three enhancing pleural based masses (white arrows in $A$ and $B$ ) in the posterior left hemithorax.

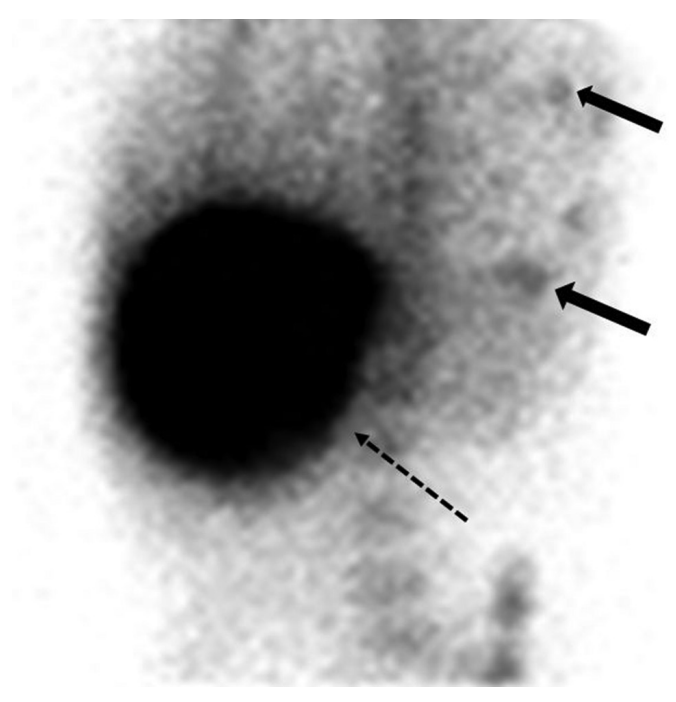

Figure 2 Sagittal oblique view of technetium $99 \mathrm{~m}$ sulfur colloid scan shows nodular uptake representing splenic tissue (black solid arrows) in the left hemithorax and normal uptake in the liver (dashed black arrows).

is required. It is usually asymptomatic and incidentally detected during workup for different reasons. There are a few reports of thoracic splenosis presenting with symptoms such as pleuritic chest pain and haemoptysis. ${ }^{1}$ It may be misdiagnosed as pleural malignancy or metastases especially if found during workup of malignancy and subjected to unnecessary invasive procedures such as biopsy or thoracoscopy for histopathological confirmation. The best clue that can lead to the correct diagnosis is the history of splenic and/or diaphragmatic trauma.

Splenosis is usually too small to be detected on chest radiograph. On CT/MRI, solitary or multiple pleural-based masses are typically detected (figure 1). CT/ MRI finding of enhancing pleural masses is non-specific with a wide differential diagnosis including mesothelioma, primary lung cancer, lymphoma, thymoma, neurological tumour and metastasis. MRI would help in tissue characterisation, especially diffusion-weighted imaging. Normal as well as accessory spleen has the greatest non-pathological restricted diffusion among solid abdominal organs. ${ }^{2}$ Thus, splenic tissue in the thorax will produce a high signal mass on a background of low signal on the diffusion-weighted images. Nuclear medicine studies can confirm the diagnosis. Technetium $99 \mathrm{~m}$ sulfur colloid is sequestered in the reticuloendothelial system and thus, in any splenic tissue. Any focal uptake in the left hemithorax corresponding to the CT abnormality confirms the diagnosis (figure 2). ${ }^{3}$ 


\section{Learning points}

Thoracic splenosis should be considered in the differential diagnosis of enhancing pleural masses in the thorax.

- It should be suspected in patients with history of splenic and/ or diaphragmatic trauma.

- Diagnosis can be confirmed by nuclear medicine studies, thereby avoiding inadvertent invasive procedures like biopsy or thoracoscopy.

Contributors RT did literature search and wrote the manuscript with support from CRT. RT obtained patient consent. CRT provided images and clinical details of the patient for the case.
Funding The authors have not declared a specific grant for this research from any funding agency in the public, commercial or not-for-profit sectors.

Competing interests None declared.

Patient consent Obtained.

Provenance and peer review Not commissioned; externally peer reviewed.

\section{REFERENCES}

1 Syed S, Zaharopoulos P. Thoracic splenosis diagnosed by fine-needle aspiration cytology: a case report. Diagn Cytopathol 2001;25:321-4.

2 Morani AC, Elsayes KM, Liu PS, et al. Abdominal applications of diffusion-weighted magnetic resonance imaging: Where do we stand. World J Radiol 2013;5:68-80.

3 Armas RR. Clinical studies with spleen-specific radiolabeled agents. Semin Nucl Med $1985 ; 15: 260-75$.

Copyright 2018 BMJ Publishing Group. All rights reserved. For permission to reuse any of this content visit http://group.bmj.com/group/rights-licensing/permissions.

BMJ Case Report Fellows may re-use this article for personal use and teaching without any further permission.

Become a Fellow of BMJ Case Reports today and you can:

- Submit as many cases as you like

- Enjoy fast sympathetic peer review and rapid publication of accepted articles

- Access all the published articles

- Re-use any of the published material for personal use and teaching without further permission

For information on Institutional Fellowships contact consortiasales@bmjgroup.com

Visit casereports.bmj.com for more articles like this and to become a Fellow 